Do process innovations boost SMEs productivity growth?

WP-EC 2009-12 Juan A. Máñez-Castillejo, M. Engracia Rochina-Barrachina, Amparo Sanchis-Llopis and Juan A. Sanchis-Llopis 
Los documentos de trabajo del Ivie ofrecen un avance de los resultados de las investigaciones económicas en curso, con objeto de generar un proceso de discusión previo a su remisión a las revistas científicas. Al publicar este documento de trabajo, el Ivie no asume responsabilidad sobre su contenido.

Ivie working papers offer in advance the results of economic research under way in order to encourage a discussion process before sending them to scientific journals for their final publication. Ivie's decision to publish this working paper does not imply any responsibility for its content.

La Serie EC, coordinada por Matilde Mas, está orientada a la aplicación de distintos instrumentos de análisis al estudio de problemas económicos concretos.

Coordinated by Matilde Mas, the EC Series mainly includes applications of different analytical tools to the study of specific economic problems.

Todos los documentos de trabajo están disponibles de forma gratuita en la web del Ivie http://www.ivie.es, así como las instrucciones para los autores que desean publicar en nuestras series.

Working papers can be downloaded free of charge from the Ivie website http://www.ivie.es, as well as the instructions for authors who are interested in publishing in our series.

Edita / Published by: Instituto Valenciano de Investigaciones Económicas, S.A.

Depósito Legal / Legal Deposit no.: V-4043-2009

Impreso en España (octubre 2009) / Printed in Spain (October 2009) 


\title{
Do process innovations boost SMEs productivity growth?*
}

\author{
Juan A. Máñez-Castillejo, M. Engracia Rochina-Barrachina, \\ Amparo Sanchis-Llopis and Juan A. Sanchis-Llopis*
}

\begin{abstract}
In this paper we explore in depth the effect of process innovations on total factor productivity growth for small and medium enterprises (SMEs), taking into account the potential endogeneity problem that may be caused by self selection into these activities. First, we analyse whether the ex-ante most productive SMEs are those that start introducing process innovations; then, we test whether process innovations boost SMEs productivity growth using matching techniques to control for the possibility that selection into introducing process innovations may not be a random process. We use a sample of Spanish manufacturing SMEs for the period 1991-2002, drawn from the Encuesta sobre Estrategias Empresariales. Our results show that the introduction of process innovations by a first-time process innovator yields an extra productivity growth as compared to a non-process innovator, and that the life span of this extra productivity growth has an inverted U-shaped form.
\end{abstract}

Keywords: process innovations, TFP, stochastic dominance, matching techniques.

JEL Classification: C12, C14, D2, D24, L6, O3, L26

\section{Resumen}

En este artículo se exploran los posibles efectos de la introducción de innovaciones de proceso en el crecimiento de la productividad de las pequeñas y medianas empresas (PYMES). Para ello se presta especial atención a la existencia de un problema de selección no aleatorio en la implementación de tales innovaciones. En primer lugar, se analiza si son aquellas empresas $e^{x-}$ ante más productivas las que introducen innovaciones de proceso. A continuación, se utilizan técnicas de matching para contrastar si la implementación de innovaciones de proceso acelera el crecimiento de la productividad de las PYMES. La utilización de técnicas de matching permite controlar la posible existencia de un proceso de selección no aleatorio en la implementación de innovaciones de proceso. El análisis empírico se lleva cabo usando una muestra de PYMES manufactureras españolas extraída de la Encuesta sobre Estrategias Empresariales. Nuestros resultados muestran que la implementación de innovaciones de proceso por parte de PYMES sin experiencia previa en la introducción de tales innovaciones, produce un crecimiento extra de la productividad de estas PYMES en comparación con el de aquellas PYMES que no implementan innovaciones de proceso. Adicionalmente, nuestros resultados sugieren la existencia de una relación en forma de $\mathrm{U}$ invertida entre el crecimiento extra de la productividad y el tiempo transcurrido desde la introducción de la innovación de proceso.

Palabras claves: innovaciones de proceso, PTF, dominancia estocástica, técnicas de matching.

\footnotetext{
* Financial support from the Spanish Ministry of Science and Technology (project numbers ECO200804576/ECON and ECO2008-06395-C05-03) is gratefully acknowledged. We are grateful to participants in the 2nd Workshop on Entrepreneurship Statistics (Huelva, Spain), and the 7th Annual International Industrial Organization Conference (Boston). We would also like to thank Fundación SEPI for providing the data. Usual disclaimers apply.

** J.A. Máñez-Castillejo: University of Valencia. Corresponding author: jamc@uv.es. M.E. RochinaBarrachina, A. Sanchis-Llopis and J.A. Sanchis-Llopis: University of Valencia \& ERI-CES.
} 


\section{Introduction}

It has been broadly recognised the role of small and medium enterprises (SMEs henceforth) as a driving force for economic growth. SMEs are crucial to the revitalization of the economy, and to the preservation and generation of employment, what is especially important when the economy undergoes severe circumstances. Fostering SMEs productivity, as a way to ensure their survival and growth in the economy, is therefore a major issue, both to managers and policy makers. Amongst the determinants of firms productivity growth, the key role of innovation has also been generally acknowledged, starting with the seminal works of Schumpeter $(1934,1942)$ and his concept of creative destruction as the mechanism driving and shaping the evolution of markets and economic growth.

A number of empirical papers have analysed the links between firms' innovation output and productivity growth using a production function approach. A remarkable example of this approach is Crépon et al. (1998), where the production function includes innovation output (patents per employee or the share of innovative sales) as a determinant of productivity growth. In this line, Verspagen (1999), Gu and Tang (2003), Huergo and Jaumandreu (2004), Parisi et al. (2006), Lee and Kang (2007), and Rochina-Barrachina et al. (2008), considering direct measures of innovation output (such as patents, products or process innovations), find that process innovations have a positive impact on firms productivity. However, despite the acknowledgement of this positive relationship, little is known about the direction of causality between firms' process innovations and productivity. In particular, do process innovations enhance firms' productivity growth, or are the most productive firms becoming process innovators, or both? Discerning the direction of this causality is important in order to draw conclusions that may guide firms’ strategies.

In this paper we depart from previous studies by explicitly exploring the causal links between process innovations and productivity, that is, by taking into account the potential endogeneity problem characterizing this relationship: the introduction of process innovations may increase SMEs' productivity, but it may also be the case that only the most productive SMEs are able to generate the resources needed to implement process innovations. To properly assess the impact of the introduction of process innovations on firms' productivity, dealing with this problem of endogeneity constitutes an econometric challenge, and in this paper we address this issue using appropriate econometric techniques. 
The aim of this paper is to explore in depth the direct effect of process innovations on total factor productivity (TFP, hereafter) for SMEs. In particular, we aim to analyze both the extent and the life span of the productivity gains brought about by the introduction of process innovations, taking into account the potential endogeneity problem between process innovation and productivity growth. In order to do this, we proceed in two steps. Firstly, we analyse whether the ex-ante most productive SMEs are those that start introducing process innovations. Second, we test whether process innovations boost SMEs productivity growth using matching techniques to control for the possibility that selection into introducing process innovations may not be a random process. The matching techniques allow us testing whether the future productivity path is affected by the introduction of process innovations.

To perform the analysis, we use data on SMEs drawn from the Encuesta sobre Estrategias Empresariales (ESEE, hereafter) for the period 1991-2002. This survey data is representative of Spanish manufacturing SMEs classified by industrial sectors and size categories. ${ }^{1}$ The panel data nature of the data set allows classifying SMEs according to their process innovation patterns over time and to analyze the extent and the life span of the impact of process innovations on SMEs productivity growth. The empirical work is carried out using both stochastic dominance and matching techniques.

Our paper contributes to the empirical literature dealing with the measurement of the impact of innovation output on productivity growth using firm level data. To our knowledge, this paper is the first to look at the productivity gains from introducing process innovations at the firm level using matching techniques to deal with the potential endogeneity problem that may arise from self selection into these activities.

To anticipate our results, we find that the introduction of process innovations yields a delayed (not contemporaneous) extra productivity growth to a SME implementing a process innovation for the first time, as compared to a SME that does not introduce process innovations, and that this extra productivity growth has an inverted U-shaped form. These findings shed light on the understanding of the links between process innovation and SMEs productivity growth and thus may serve to assist not only the design of management strategies but also more effective policies to promote SMEs. From a strategic management point of view, our results may be used to outline managerial recommendations relating the rate and timing of introducing process

1 The ESEE does not include SMEs with less than 10 employees. Therefore, given the sampling procedure of this survey, we consider as SMEs those firms having between 10 and 200 employees. See section 3 for details. 
innovations as a strategic tool to boost productivity growth, and in turn, to improve the competitive position of the firm in the market. Our findings also suggest that public policy should be on support of innovative SMEs, and in particular, on undertaking and developing initiatives aimed at facilitating SMEs the introduction of process innovations, such as tax incentives, access to finance and grant schemes, and also incentives heading for the maintenance and improvement of SMEs skills to innovate and to adapt and develop new technologies. This issue is especially important in Europe since increasing the share of innovative SMEs in the overall industrial sector is one of Europe's major challenges.

The rest of the paper is organized as follows. Section 2 briefly describes the relationship between process innovations and SMEs productivity. Section 3 presents the data. Section 4 analyses whether the ex-ante most productive SMEs are those that start introducing process innovations. Section 5 examines whether process innovations boost SMEs productivity growth. Finally, section 6 concludes.

\section{Process innovations and productivity for SMEs}

Our focus in this paper is to analyse the impact of process innovations on SMEs' productivity. On theoretical grounds, there are, at least, three strands in the literature supporting a positive relationship between the introduction of process innovations and firms' productivity growth. The first strand is based on the well-known $R \& D$ capital stock model of Griliches (1979) that analyses the relationship among R\&D investments, achievement of innovations and productivity growth. Since this seminal work, other authors have incorporated more explicitly the role of process innovations on productivity growth. For instance, Klette and Johansen (1998) incorporated the output elasticity of knowledge capital to point out the opportunity for process innovations, and Smolny (1998) assumed that process innovations reduce production costs by increasing the productivity of labour and/or capital. The second strand in the literature rendering theoretical support to the relationship between process innovations and productivity growth is the active learning model (Ericson and Pakes, 1992, 1995, and Pakes and Ericson, 1998). According to this model, R\&D investments, if successful, contribute to improve firm' productivity over time. If the successful output of firms R\&D activities is the production of a process innovation and this is actually implemented, we expect an increase in the productivity growth of such a firm. Therefore, in the active learning model the relationship between $R \& D$ activities and productivity growth runs through the achievement and implementation of process innovations. Finally, endogenous 
growth theory is the third strand of the literature stressing the importance of innovations for productivity growth (see, e.g., Romer, 1990, Aghion and Howitt, 1992).

Our interest in SMEs is not only because they have grown into an important force in the world economy, but also because the introduction of process innovations may constitute an important source of competitive advantage for these companies, as compared to their larger counterparts. In the case of Spain, SMEs represent $96.78 \%$ of total firms, $64.08 \%$ of total employment, $53.08 \%$ of total sales and $33.78 \%$ of total R\&D expenditures. Given their organizational simplicity, SMEs may implement process innovations faster and at lower switching costs than large firms (Buckley and Mirza, 1997). In addition, due to the limited resources and small scale production, SMEs may find easier to follow an innovation strategy aimed at obtaining direct rewards in terms of productivity, such as process innovations, rather than investing huge amounts in the development of sophisticated $R \& D$ projects, and indeed, there is empirical evidence supporting the view that SMEs are process innovation oriented (see Acs and Audretsch, 1990, Baldwin, 1997, Smolny, 1998, among others). Thus, for a number of reasons, the introduction of process innovations may be considered as an important tool of strategic management for SMEs. ${ }^{2}$

\section{Data, productivity and process innovation status for SMEs}

The data used in this paper are drawn from the ESEE for the period 1991-2002. This is an annual survey that is representative of Spanish manufacturing firms classified by industrial sectors and size categories. It provides exhaustive information at the firm level, including information on innovation activities performed by firms. As for SMEs, the sampling procedure of the ESEE excluded those firms with less than 10 employees, and firms with 10 to 200 employees were randomly sampled, holding around 5\% of the population in 1990. Important efforts have been made to minimise attrition and to annually incorporate new firms with the same sampling criteria as in the base year, so that the sample of firms remains representative of the Spanish manufacturing SMEs over time. ${ }^{3}$ The total sample of SMEs corresponding to the period 1991-2002, is made up of 12929 observations. This means an annual average of 1077 SMEs throughout the entire period.

\footnotetext{
2 There is also empirical evidence showing that large firms are more process R\&D-oriented, as compared to other innovation strategies, than small firms (see, e.g. Davies, 1979, Sherer, 1991, Pavitt et al., 1987, Cohen and Klepper, 1996). However, this is not inconsistent with the fact that SMEs are more prone to implement process innovations.

${ }^{3}$ See http://www.funep.es/esee/ing/i_esee.asp for further details.
} 
The panel nature of the dataset allows classifying SMEs according to their innovative activities over time (process innovations in our case). The particular question in the ESEE is as follows: "Indicate if during 199X the SME introduced some important modification of the productive process (process innovation)”. To measure productivity we use a TFP index. This is calculated at the firm level using a multilateral productivity index that is an extension of the Caves et al. (1982) index. ${ }^{4}$ The information provided by the ESEE allows us to deflate both output and inputs using, correspondingly, firm individual price indexes drawn from the survey. This is good to control for the possibility of output and input prices not only being different or evolving differently over time for process innovators than non innovators but also between firms, irrespective to their process innovation status. Therefore, our TFP measure to some extent reflects firm differences in market conditions. We select those SMEs that report information both on the process innovation question and on all the variables involved in the construction of the productivity measure. Applying this criterion we end up with a sample of 11626 observations (see Table 1$).^{5}$

Table 1. Yearly number of SMEs and process innovators

\begin{tabular}{lcc}
\hline Years & Total & Process innovators \\
\hline 1991 & 683 & 205 \\
1992 & 848 & 260 \\
1993 & 985 & 301 \\
1994 & 967 & 302 \\
1995 & 910 & 269 \\
1996 & 969 & 272 \\
1997 & 1129 & 374 \\
1998 & 1036 & 353 \\
1999 & 1068 & 338 \\
2000 & 1049 & 333 \\
2001 & 991 & 269 \\
2002 & 991 & 237 \\
\hline Total 1991-2002 & 11626 & 3513 \\
\hline
\end{tabular}

In order to get a first picture of the relationship between process innovations and SMEs productivity, we check whether SMEs introducing process innovations present higher productivity levels than SMEs that do not introduce them.

Figure 1 displays the relative distribution functions of TFP for SMEs process innovators in $t$ and non process innovators in $t$, respectively, for each year of the period

\footnotetext{
${ }^{4}$ This extension was developed in Good et al. (1996) and Delgado et al. (2002). It may also be found in Máñez-Castillejo et al. (2005) and Rochina-Barrachina et al. (2008).

${ }^{5}$ We do not use any observation for 1990 as we cannot compute TFP for this year in the survey.
} 
1991-2002. ${ }^{6}$ These figures represent the equivalence between each of the quantiles of the TFP distribution for SMEs that have achieved process innovations in the quantile scale of the TFP distribution for non-process innovators SMEs. The diagonal represents the uniform distribution [0,1], i.e. the relative distribution if both distributions were identical. The position of the relative distribution below the diagonal suggests that the distribution represented in the vertical axis stochastically dominates the distribution in the horizontal axis. In particular, the relative TFP distribution for process innovating SMEs lies below the diagonal for ten out of twelve years (except for 1991 and 1992), suggesting that the TFP distribution for SMEs process innovating in $t$ stochastically dominates that for the non-process innovators in each period $t$.

\section{Figure 1. Yearly relative TFP distribution functions of process innovators in $t$ to non-process innovators in $t$}

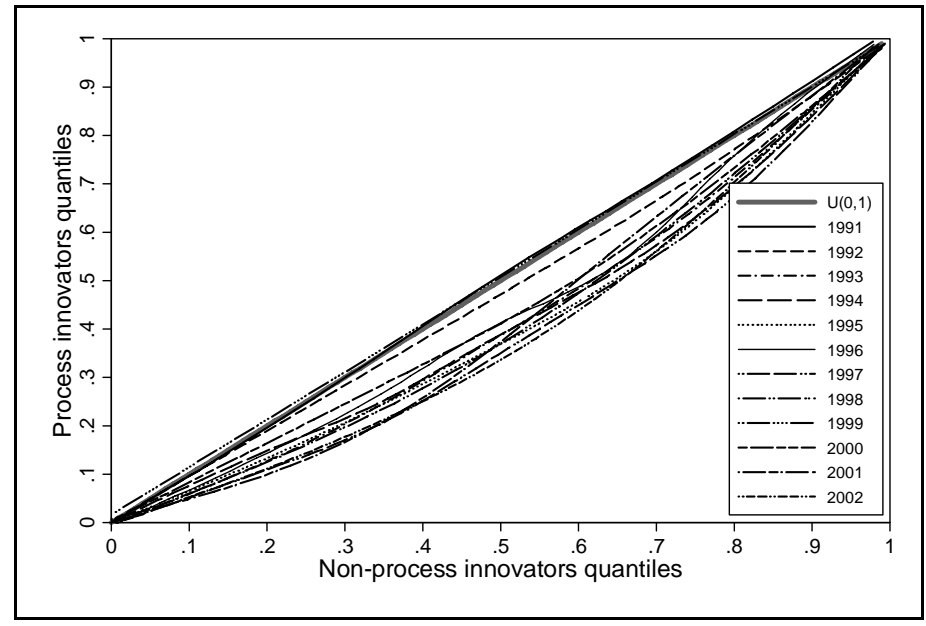

On the basis of the observed differences in Figure 1, we formally test whether the TFP distribution of SMEs process innovators in $t$ stochastically dominates the TFP distribution of non process innovators in $t$. Thus, for each time period, we compare

$$
F_{t}\left(y_{t}\right) \text { vs. } G_{t}\left(y_{t}\right), \quad t=1991, \ldots, 2002
$$

using the Kolmogorov-Smirnov (KS, hereafter) one and two-sided tests, where $F_{t}$ and $G_{t}$ are the yearly TFP distribution functions for SMEs process innovators and non process innovators in $t$, respectively. ${ }^{7}$

\footnotetext{
${ }^{6}$ See Handcock and Morris (1999) for the technical details about relative distributions.

${ }^{7}$ See Delgado et al. (2002) for a description of the application of the Kolmogorov-Smirnov tests for the testing of stochastic dominance.
} 
Table 2 shows the results for the KS tests for TFP differentials. We reject the null hypothesis of equality of the two distributions (at a 5\% significance level) for all years, except for 1991 and 1992. Further, we can never reject the null that the TFP of SMEs implementing process innovations in $t$ is higher than that of non-process innovators. Thus, in general terms, process innovators are more productive in terms of TFP than non-process innovators.

\section{Self selection of the most productive SMEs into implementing process innovations}

We now proceed to check whether among non-process innovators today, those that will introduce process innovations in the future are ex-ante more productive than those that will not. If (future) process innovators are ex-ante more productive, one would find that these firms would experience higher productivity in the future even without introducing process innovations. We want to test whether the most productive SMEs self select into obtaining process innovations. On theoretical and empirical grounds, we expect the productivity level of process innovators to be not lower than that of non-process innovators as: (i) the expenditures associated to innovation activities (both formal and informal) limit the access to innovation activities to the most productive firms; ${ }^{8}$ and, (ii) performing innovation activities might be a previous condition to obtain process innovations. ${ }^{9}$

Thus, as a first step, we test for non-random selection into implementing process innovation, that is, we first test whether among non-process innovators in $t$ - 1 , those introducing process innovations in $t$ are more productive in $t-1$. In order to do so, we compare TFP (previous to obtaining a process innovation) of SMEs implementing a process innovation for the first time, with TFP of non-process innovators. We define first-time process innovating SMEs in $t$ as those SMEs that implement a process innovation for the first time (in our sample period) in period $t$; and, as non-process innovators those SMEs that have not implemented a process innovation until $t$ - 1 , and do not implement it at time $t$ either. However, the small size of first-time process innovators cohorts between 1992 and 2002 (reported in table 3) suggests not carrying out year-by-year KS tests as their results would be scarcely reliable.

\footnotetext{
${ }^{8}$ This is especially relevant for the case of R\&D investments due to its sunk costs nature (Sutton, 1991, Máñez et al., 2009).

${ }^{9}$ Some support for the self-selection hypothesis into R\&D activities (formal part of innovation activities) of the most productive firms can be found, among others, in Hall, 1990 (who uses a financial constraint argument), González and Jaumandreu, 1998, González et al., 1999, and Máñez et al., 2005.
} 
Table 2. Yearly TFP differences between SMEs first-time process innovators in $t$ and non-process innovators in $t$

\begin{tabular}{|c|c|c|c|c|c|c|c|}
\hline \multirow[b]{2}{*}{ Year } & \multicolumn{2}{|c|}{ Number of observations } & \multirow[b]{2}{*}{$\begin{array}{c}\text { TFP } \\
\text { differences }^{\mathrm{a}}\end{array}$} & \multicolumn{2}{|c|}{ Equality of distributions } & \multicolumn{2}{|c|}{$\begin{array}{l}\text { Differences favourable to first time } \\
\text { process innovators }\end{array}$} \\
\hline & $\begin{array}{c}\text { First-time } \\
\text { process } \\
\text { innovators }\end{array}$ & $\begin{array}{l}\text { Non-process } \\
\text { innovators }\end{array}$ & & Statistic & $p$-value & Statistic & $p$-value \\
\hline 1991 & 205 & 478 & 0.002 & 0.387 & 0.998 & 0.309 & 0.826 \\
\hline 1992 & 260 & 588 & 0.026 & 0.970 & 0.272 & 0.206 & 0.918 \\
\hline 1993 & 301 & 684 & 0.068 & 1.866 & 0.001 & 0.098 & 0.981 \\
\hline 1994 & 302 & 665 & 0.054 & 2.164 & 0.000 & 0.022 & 0.999 \\
\hline 1995 & 269 & 641 & 0.066 & 2.095 & 0.000 & 0.086 & 0.985 \\
\hline 1996 & 272 & 697 & 0.045 & 2.001 & 0.000 & 0.257 & 0.876 \\
\hline 1997 & 374 & 755 & 0.067 & 2.644 & 0.000 & 0.021 & 0.999 \\
\hline 1998 & 353 & 683 & 0.054 & 2.094 & 0.000 & 0.003 & 1.000 \\
\hline 1999 & 338 & 730 & 0.053 & 2.719 & 0.000 & 0,092 & 0.983 \\
\hline 2000 & 333 & 716 & 0.036 & 1.809 & 0.002 & 0,069 & 0.990 \\
\hline 2001 & 269 & 722 & 0.037 & 2.206 & 0.000 & 0,306 & 0.829 \\
\hline 2002 & 237 & 754 & 0.060 & 2.419 & 0.000 & 0,175 & 0.941 \\
\hline
\end{tabular}

a TFP differences (between both groups of SMEs) are calculated at the median of the distributions.

Table 3. Yearly number of SMEs first-time process innovators

\begin{tabular}{cc}
\hline Year & \\
\hline 1992 & 47 \\
1993 & 51 \\
1994 & 36 \\
1995 & 30 \\
1996 & 21 \\
1997 & 28 \\
1998 & 43 \\
1999 & 26 \\
2000 & 24 \\
2001 & 33 \\
2002 & 12 \\
\hline Total 1992-2002 & 351
\end{tabular}

a We do not report data for 1991 as we need to start the test from 1992 onwards to calculate t-1 TFP. 
To overcome this limitation we apply this test jointly for the whole sample period. Therefore, we compare,

$$
F_{1991, \ldots, 2001}\left(z_{1991, \ldots, 2001}\right) \text { vs. } G_{1991, \ldots, 2001}\left(z_{1991, \ldots, 2001}\right)
$$

where $F_{1991, \ldots, 2001}$ is the previous TFP distribution of the eleven cohorts of firsttime process innovators, and $G_{1991, \ldots, 2001}$ is the yearly average TFP distribution over the period 1991-2001 for the non-process innovators.

To obtain the previous TFP distribution function of first-time process innovators we follow two alternative approaches. In the first one, this distribution is calculated using TFP in $t$-1 of first-time process innovators in $t$, for $t=1992, \ldots, 2002$. In the second approach, this distribution is constructed with the previous average TFP, starting from the first year a SME is observed in the sample until $t-1$.

Figures 2(a) and 2(b) map the kernel estimates of the cumulative previous TFP distribution functions of first-time process innovators and non-process innovators using the two alternative approaches defined above. We may observe from the figures that, independently of the approach used to calculate previous TFP distribution of first-time process innovators, the distribution of first-time process innovators is to the right of that of non-process innovators, suggesting that SMEs that eventually introduce process innovations had higher TFP levels than non-process innovators previously to implementing a process innovation.

Further, the results of formal KS tests of stochastic dominance using the two approaches described above confirm the patterns of stochastic dominance suggested by our graphical regularities (see Table 4). Thus, regardless the approach considered, we always reject the null hypothesis of equality of TFP distributions and we cannot reject the null hypothesis (at any reasonable significance level) of favourable differences to first-time process innovators. Therefore, the KS tests indicate that SMEs that eventually introduce process innovations exhibited higher previous TFP levels than their nonprocess innovators counterparts. Thus, we find evidence on the existence of non-random selection into the introduction of process innovations that should be taken into account when analyzing the effects of process innovations in SMEs productivity growth. ${ }^{10}$

\footnotetext{
${ }^{10}$ Rochina-Barrachina et al. (2008) also found evidence of self selection into the introduction of process innovations by the most productive Spanish manufacturing firms for the period 1991-1998.
} 
Figure 2. Comparing the TFP growth of first-time process innovators and non-process innovators

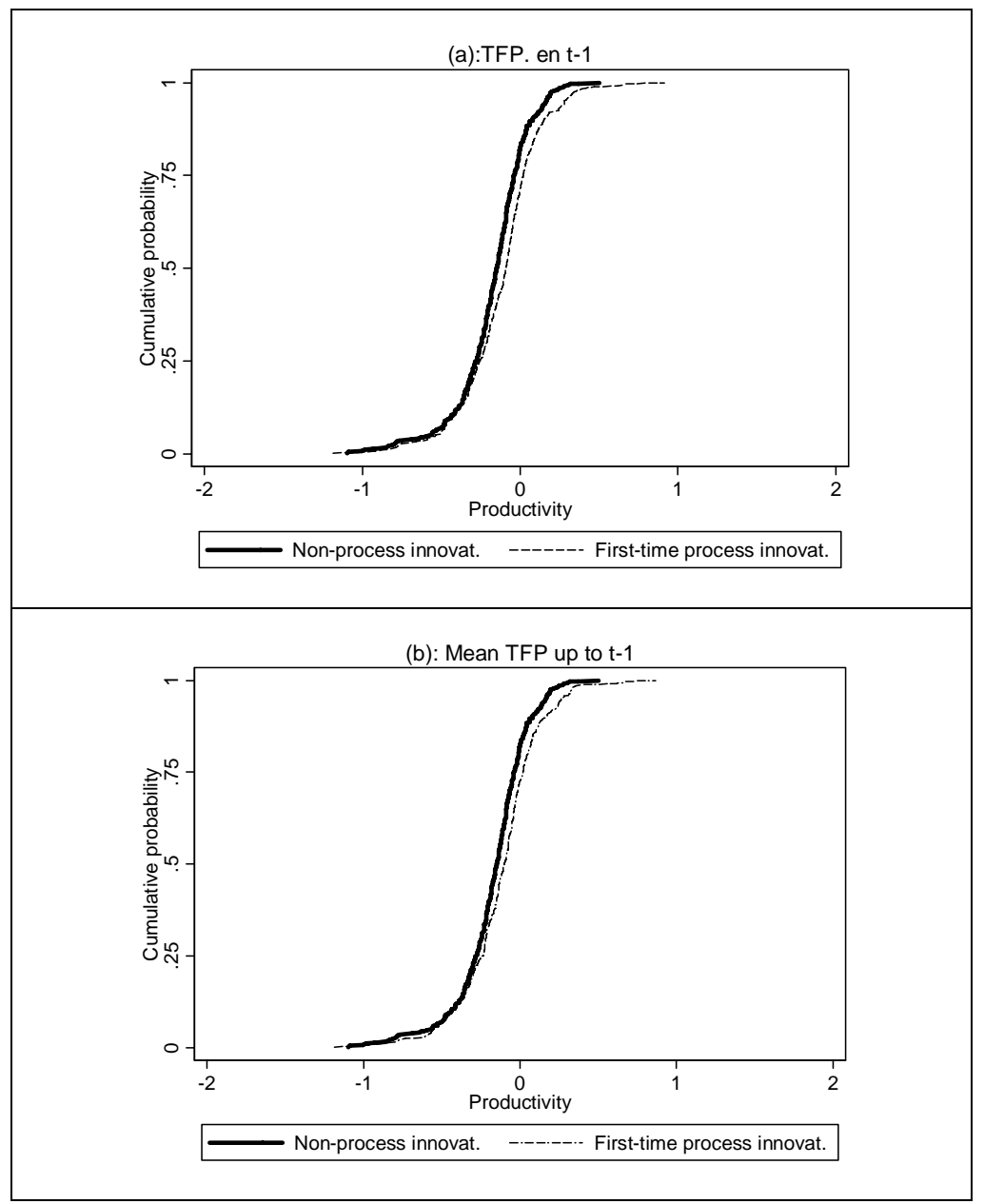


Table 4. Comparison of previous TFP of SMEs first-time process innovators and non-process innovators

\begin{tabular}{|c|c|c|c|c|c|c|c|}
\hline & & & & \multicolumn{2}{|c|}{ Equality of distributions } & \multicolumn{2}{|c|}{$\begin{array}{l}\text { Favourable diff. to first-time } \\
\text { process innovators }\end{array}$} \\
\hline & $\begin{array}{c}\text { First-time } \\
\text { process } \\
\text { innovators }\end{array}$ & $\begin{array}{l}\text { Non-process } \\
\text { innovators }\end{array}$ & TFP diffs. ${ }^{a}$ & Statistic & $p$-value & Statistic & $p$-value \\
\hline $\begin{array}{l}\text { TFP in } t-1 \text { for first-time } \\
\text { process innovators }\end{array}$ & 351 & 334 & 0.061 & 1.969 & 0.004 & 0.050 & 0.995 \\
\hline $\begin{array}{l}\text { Mean previous TFP for first- } \\
\text { time process innovators }\end{array}$ & 351 & 334 & 0.052 & 1.843 & 0.016 & 0.215 & 0.912 \\
\hline
\end{tabular}

a TFP differences (between both groups of SMEs) are calculated at the median of the distributions. 


\section{Do process innovations boost SMEs productivity growth?}

If selection into introducing process innovations is endogenous, it is not appropriate to assess the impact of introducing process innovations on SMEs productivity growth by simply comparing the TFP growth of first-time process innovators and non-process innovators, since the ex-ante more productive first time process innovators would experience higher productivity in the future even without introducing any process innovation. To properly control for the direction of causality from implementing process innovations to productivity growth, one needs to use a methodology that explicitly takes into account this endogenous selection process.

More formally, let $\Delta y$ denote the growth rate of TFP and $D_{i t} \in\{0,1\}$ be an indicator of whether SME $i$ is a first-time process innovator in period $t$ (as opposed to a non-process innovator). Therefore, we can use $\Delta y_{i(t-1)+s}^{1}$ to define the TFP growth between $t-1$ and $(t-1)+s, s>0$, for SME $i$ classified as first-time process innovator in $t$, and $\Delta y_{i(t-1)+s}^{0}$ as the TFP growth for SME $i$ should it had not implemented any process innovation. Thus, the causal effect of implementing a first process innovation for SME $i$ at time period $(t-1)+s$ may be defined as

$$
\Delta y_{i(t-1)+s}^{1}-\Delta y_{i(t-1)+s}^{0}
$$

Following the policy/treatment evaluation literature (see Heckman et al., 1997), we may define the average effect of implementing a process innovation for the first time on SMEs productivity as

$$
E\left(\Delta y_{i(t-1)+s}^{1}-\Delta y_{i(t-1)+s}^{0} \mid D_{i t}=1\right)=E\left(\Delta y_{i(t-1)+s}^{1} \mid D_{i t}=1\right)-E\left(\Delta y_{i(t-1)+s}^{0} \mid D_{i t}=1\right)
$$

The main problem of causal inference is that in observational studies the counterfactual $\Delta y_{i(t-1)+s}^{0}$ for a SME that introduced a process innovation is not observed, and therefore it has to be generated. Thus, causal inference relies on the construction of the counterfactual for this term, which is the average productivity growth that first timeprocess innovators would have experienced had they not implemented any process innovation. We overcome this problem using matching techniques to identify, among the pool of non-process innovators in $t$, those with a distribution of observable variables $(X$ in $t-1$ ) affecting productivity growth and the probability of implementing a process innovation, as similar as possible to that of first-time process innovators in $t-1$. It is then assumed that, conditional on $X$, SMEs with the same characteristics have a random 
probability to implement a process innovation. Thus, $E\left(\Delta y_{i(t-1)+s}^{1}-\Delta y_{i(t-1)+s}^{0} \mid X_{i t-1}, D_{i t}=1\right)$ in expression (4) may be rewritten as

$$
E\left(\Delta y_{i(t-1)+s}^{1} \mid X_{i t-1}, D_{i t}=1\right)-E\left(\Delta y_{i(t-1)+s}^{0} \mid X_{i t-1}, D_{i t}=0\right)
$$

Since the set of observable variables that may potentially affect the SMEs probability of implementing a process innovation and their productivity growth is quite large, we need to deal with the choice of the appropriate variables to match SMEs, and their appropriate weights. We solve this problem using the propensity score techniques proposed by Rosenbaum and Rubin (1983). Adapted to process innovations, it may be shown that if implementing a first process innovation is random conditioning upon $X$, it is also random conditioning on the probability of implementing a process innovation.

Therefore, before performing the matching procedure, we obtain the probability of implementing a process innovation for the first time (propensity score) as the predicted probability in the following probit model

$$
P\left(D_{i t}=1\right)=F\left(X_{i t-1}\right)
$$

To causally identify the effect of process innovations on productivity we control for past productivity and other lagged firm characteristics. The most important variable in the propensity score estimation is lagged productivity, as it allows controlling for the self selection of the most productive firms into process innovation activities. Further, by including other important firm variables that could be linked to increased productivity we ensure that productivity growth differentials between firms introducing process innovations and its non process innovation counterparts are driven by the introduction of process innovations. ${ }^{11}$ Both the results from the probit and the set of observable characteristics included in $X_{i t-1}$ are in Table A.1 in the Appendix.

With the aim of ensuring the robustness of our results, to construct the counterfactual we have used three different types of matching, namely, nearest neighbours, radius matching and kernel matching. Nearest neighbours matches firsttime process innovators with an average of the $k$ non-process innovators with the closest propensity score. Radius matching matches first-time process innovators with an

\footnotetext{
${ }^{11}$ Our TFP index itself also allows controlling for industry factors that may also condition firms' productivity. The TFP index of Good et al. (1996) and Delgado et al. (2002), by considering a different reference firm across industries eliminate possible differences in TFP across industries.
} 
average of the non-process innovators within a given radius. Kernel matching matches first-time process innovators with a weighted average of some (all) non-process innovators, with weights inversely proportional to the distance between the propensity score of first-time process innovators and non-process innovators. ${ }^{12}$

We compare, using matching techniques, the productivity growth of first-time process innovators and matched non-process innovators for the periods $t-1$ to $t, t$ to $t+1$, $t+1$ to $t+2, t+2$ to $t+3$ and $t+3$ to $t+4$. Table 5 reports the results of these comparisons.

\section{Table 5: Estimates of extra productivity growth for first-time process innovators}

\begin{tabular}{lllll}
\hline Period & Matching method & EPG & s.e. & Obs \\
\hline $\mathrm{t}-1 / \mathrm{t}$ & & & & \\
& Nearest neighbours (A\&I) & -0.0170 & 0.0138 & $345(1316)$ \\
& Nearest neighbours (ss) & -0.0170 & 0.0147 & $345(1316)$ \\
& Radius matching & -0.0185 & 0.0137 & $345(1319)$ \\
& Kernel matching & -0.0178 & 0.0136 & $345(1319)$ \\
\hline $\mathrm{t} / \mathrm{t}+1$ & Nearest neighbours (A\&I) & $0.0360^{*}$ & 0.0199 & $195(1316)$ \\
& Nearest neighbours (ss) & $0.0360^{*}$ & 0.0219 & $195(1316)$ \\
& Radius matching & $0.0357^{* *}$ & 0.0206 & $195(1319)$ \\
& Kernel matching & $0.0368^{* *}$ & 0.0201 & $195(1319)$ \\
\hline $\mathrm{t}+1 / \mathrm{t}+2$ & Nearest neighbours (A\&I) & $0.0483^{* * *}$ & 0.0164 & $132(1316)$ \\
& Nearest neighbours (ss) & $0.0483^{* * *}$ & 0.0190 & $132(1316)$ \\
& Radius matching & $0.0488^{* * *}$ & 0.0173 & $132(1319)$ \\
& Kernel matching & $0.0484^{* * *}$ & 0.0170 & $132(1319)$ \\
\hline $\mathrm{t}+2 / \mathrm{t}+3$ & Nearest neighbours (A\&I) & $0.0295^{* *}$ & 0.0142 & $93(1316)$ \\
& Nearest neighbours (ss) & $0.0295^{* *}$ & 0.0149 & $93(1316)$ \\
& Radius matching & $0.0291^{* *}$ & 0.0151 & $93(1319)$ \\
& Kernel matching & $0.0292^{* *}$ & 0.0147 & $93(1319)$ \\
\hline $\mathrm{t}+3 / \mathrm{t}+4$ & Nearest neighbours (A\&I) & -0.0154 & 0.0200 & $68(1316)$ \\
& Nearest neighbours (ss) & -0.0154 & 0.0220 & $68(1319)$ \\
& Radius matching & -0.0151 & 0.0202 & $68(1319)$ \\
& Kernel matching & -0.0151 & 0.0201 & $68(1319)$ \\
\hline & & & &
\end{tabular}

Notes:

1. EPG stands for extra productivity growth of first-time process innovators over matched non-process innovators.

2. A\&I means that standard errors have been calculated using Abadie and Imbens (2006) correction.

3. ss means that in the estimation with nearest neighbours we calculate sub-sampling based standard errors (2000 draws). For radius and kernel matching we use bootstrapped standard errors (2000 replications).

4. Kernel estimation uses the Epanechnikov Kernel.

5. Obs. stands for observations: number of first-time process innovators and number of control observations in parentheses imposing common support.

6. ${ }^{*}, * *, * *$ indicates significance at $10 \%, 5 \%$ and $1 \%$ level, respectively.

\footnotetext{
${ }^{12}$ Matching is performed using the Stata psmatch2 command (Leuven and Sianesi, 2003). Since we have previously estimated the propensity scores, $p$-values corresponding to the extra-productivity growth (EPG) are calculated using bootstrapping techniques with 2000 replications for kernel and radius matching. However, Abadie and Imbens (2006) show that due to the extreme non-smoothness of nearest neighbours matching, the standard conditions for bootstrap are not satisfied, leading the bootstrap variance to diverge from the actual variance. This may be corrected either by subsampling (Politis et al., 1999) or using the Stata nnmatch command (Abadie, Drukker, Herr and Imbens, 2004).
} 
To check the matching quality we present in Table 6 the indicators of the resulting balancing of the observable variables within the matched samples, in summary form.

Table 6. Covariate balancing indicators before and after matching

\begin{tabular}{|c|c|c|c|c|}
\hline \multicolumn{5}{|c|}{$\mathrm{N}$ and $\%$ lost to common support } \\
\hline & $\mathrm{N}$ & \multicolumn{3}{|c|}{$\%$ lost to common support } \\
\hline$t-1 / t$ & 345 & \multicolumn{3}{|c|}{0.575} \\
\hline$t / t+1$ & 195 & \multicolumn{3}{|c|}{0.510} \\
\hline$t+1 / t+2$ & 132 & \multicolumn{3}{|c|}{0.752} \\
\hline$t+2 / t+3$ & 93 & \multicolumn{3}{|c|}{1.063} \\
\hline$t+3 / t+4$ & 68 & \multicolumn{3}{|c|}{1.449} \\
\hline \multicolumn{5}{|c|}{ Probit pseudo $\mathbf{R}^{2}$} \\
\hline & & \multicolumn{3}{|c|}{ After } \\
\hline & Before & $N N$ & Radius & Kernel \\
\hline$t-1 / t$ & 0.063 & 0.004 & 0.004 & 0.002 \\
\hline$t / t+1$ & 0.041 & 0.004 & 0.004 & 0.002 \\
\hline $\mathrm{t}+1 / \mathrm{t}+2$ & 0.052 & 0.018 & 0.016 & 0.015 \\
\hline$t+2 / t+3$ & 0.050 & 0.023 & 0.017 & 0.016 \\
\hline $\mathrm{t}+3 / \mathrm{t}+4$ & 0.054 & 0.042 & 0.030 & 0.032 \\
\hline \multicolumn{5}{|l|}{$P>\chi^{2}$} \\
\hline & & \multicolumn{3}{|c|}{ After } \\
\hline & Before & $N N$ & Radius & Kernel \\
\hline $\mathrm{t}-1 / \mathrm{t}$ & 0.000 & 0.931 & 0.918 & 0.986 \\
\hline$t / t+1$ & 0.000 & 0.985 & 0.988 & 0.999 \\
\hline$t+1 / t+2$ & 0.000 & 0.672 & 0.772 & 0.795 \\
\hline$t+2 / t+3$ & 0.000 & 0.747 & 0.882 & 0.897 \\
\hline $\mathrm{t}+3 / \mathrm{t}+4$ & 0.000 & 0.537 & 0.776 & 0.744 \\
\hline \multicolumn{5}{|l|}{ Median } \\
\hline & & \multicolumn{3}{|c|}{ After } \\
\hline & Before & NN & Radius & Kernel \\
\hline $\mathrm{t}-1 / \mathrm{t}$ & 25.336 & 3.682 & 1.713 & 2.667 \\
\hline$t / t+1$ & 17.947 & 2.743 & 2.421 & 1.985 \\
\hline$t+1 / t+2$ & 25.147 & 6.667 & 4.340 & 6.101 \\
\hline$t+2 / t+3$ & 26.196 & 7.334 & 5.954 & 4.472 \\
\hline $\mathrm{t}+3 / \mathrm{t}+4$ & 23.807 & 13.994 & 8.418 & 6.340 \\
\hline
\end{tabular}

(1) NN stands for nearest neighbours matching

(2) The number of controls which are used to match treated is 1319 .

(3) Pseudo $\mathrm{R}^{2}$ from probit of treatment (implementing a process innovation in our case) on covariates before matching and in matched samples (after matching).

(4) $P>\chi^{2}$ is the $p$-value of the likelihood-ratio test after matching, testing the hypothesis that the regressors are jointly insignificant, i.e. that are well balanced in the two samples.

(5) Median bias refers to median absolute standardised bias before and after matching, the median is calculated taking over all regressors. Following Rosenbaum and Rubin (1985), for a given covariate, the standardised difference before matching is the difference of the sample means in the full treated and non-treated subsamples as a percentage of the square root of the average of the sample variances in the full treated and non-treated groups. The standardised difference after matching is the difference of the sample means in the matched treated (i.e., inside the common support) and matched non-treated subsamples as a percentage of the square root of the average of the sample variances in the full treated and non-treated groups.

(6) The \% lost to common support is the share of the treated group falling outside of the common support, imposed at boundaries. 
We may describe our results using Figure 3. In the vertical axis of this figure we represent TFP, and in the horizontal axis the sequence of time from $t-1$ onwards. The analysis of self-selection into the introduction of process innovations suggested that the previous TFP level of SMEs that eventually introduce a process innovation is higher than that of non-process innovators. As a result, the intercept of the first-time process innovators (FTPI) line is higher than that of the non-process innovators (NPI) line $\left(A>A^{\prime}\right)$.

Figure 3: Summary of results

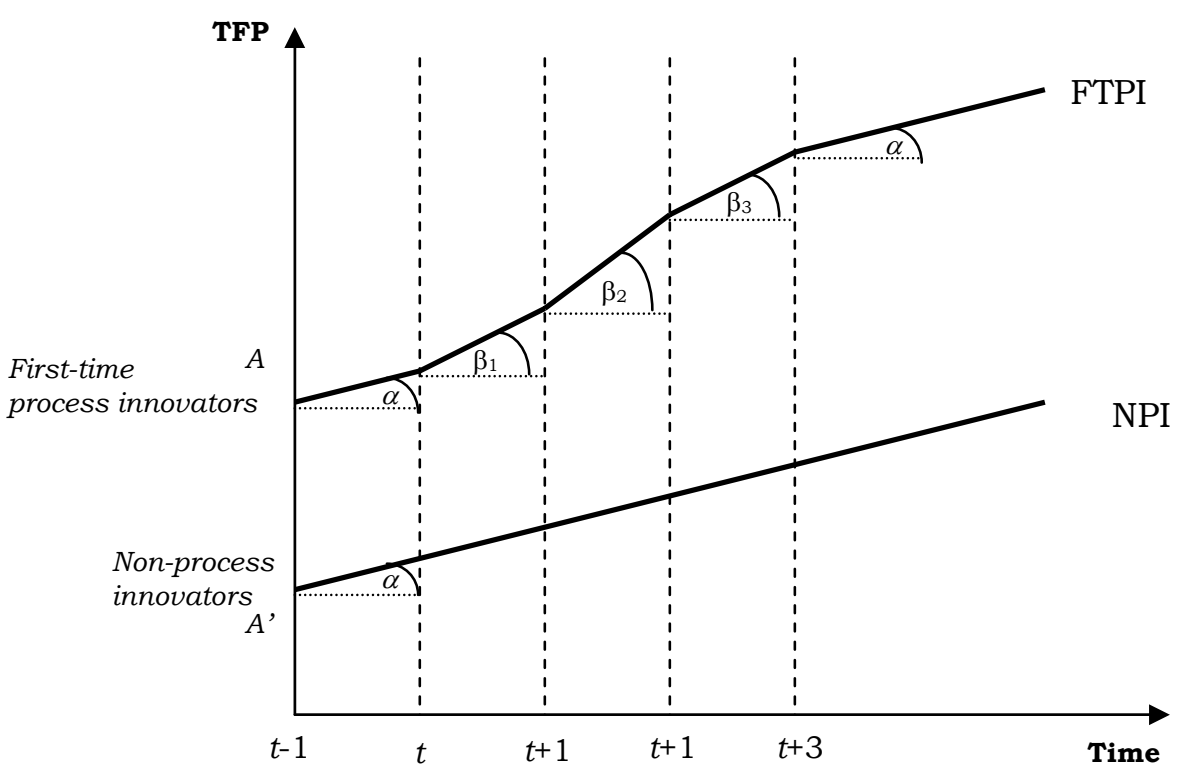

Regardless of the matching procedure, our results suggest that implementing a process innovation for the first time does not guarantee immediate productivity rewards, thus between $t-1$ and $t$ the slope $(\alpha)$ is the same for the FTPI and NPI lines. However, after its implementation, as operating experience is gained (i.e. with "learning-by-using" the new process), the process innovation is improved and developed and this in turn results in an extra productivity growth for process innovators in the subsequent periods $t / t+1, t+1$ to $t+2$ and $t+2$ to $t+3$. Thus, in Figure 3 , the slope of the FTPI line for the subperiods $t$ to $t+1, t+1$ to $t+2$ and $t+2$ to $t+3\left(\beta_{1}, \beta_{2}\right.$ and $\beta_{3}$, respectively) is greater than the slope of the NPI line $(\alpha)$. Further, this extra productivity growth that starts at $3.6 \%$ from t to $t+1$ reaches its maximum at $4.8 \%$ from $t+1$ to $t+2$, and then decreases to $2.9 \%$ from $t+3$ to $t+4$ (see Figure 4). Therefore, in Figure 3 the slope of the FTPI line for the $t+1 / t+2$ subperiod is higher than that corresponding to the $t / t+1$ and $t+2 / t+3$ subperiods $\left(\beta_{2}>\beta_{1}\right.$ and $\left.\beta_{2}>\beta_{3}\right)$. It is clear from Figure 3 that introducing a process innovation increases the productivity gap with respect to non process innovators. 
Our results also imply that after 3 years from the introduction of the process innovation the extra TFP growth of FTPI ceases, and therefore, in Figure 3, the slope of FTPI and NPI lines is the same from $t+3$ onwards (regardless of the matching procedure, there is no difference between the productivity growth of FTPI and NPI). This result suggests that as the process innovation is fully developed and exploited within the firm its potential for productivity improvement gradually fades away, so that the path of TFP growth both for process and non-process innovators converges.

Finally, Figure 4 illustrates how our results reveal an inverted U-shaped relationship between the extra productivity growth (in \%) of FTPI over NPI, and the time elapsed from the introduction of a process innovation. This inverted U-shaped relationship suggests the following: (i) implementing a process innovation for the first time does not guarantee contemporaneous productivity rewards; (ii) the productivity gains require more than one year after implementing the process innovation to take place; and, (iii) the extra-productivity growth of first-time process innovators reaches its maximum two years after the introduction of the process innovation, then decreases for one extra period and ceases after four years.

Figure 4: Percentage of extra productivity growth for first-time process innovators over non-process innovators

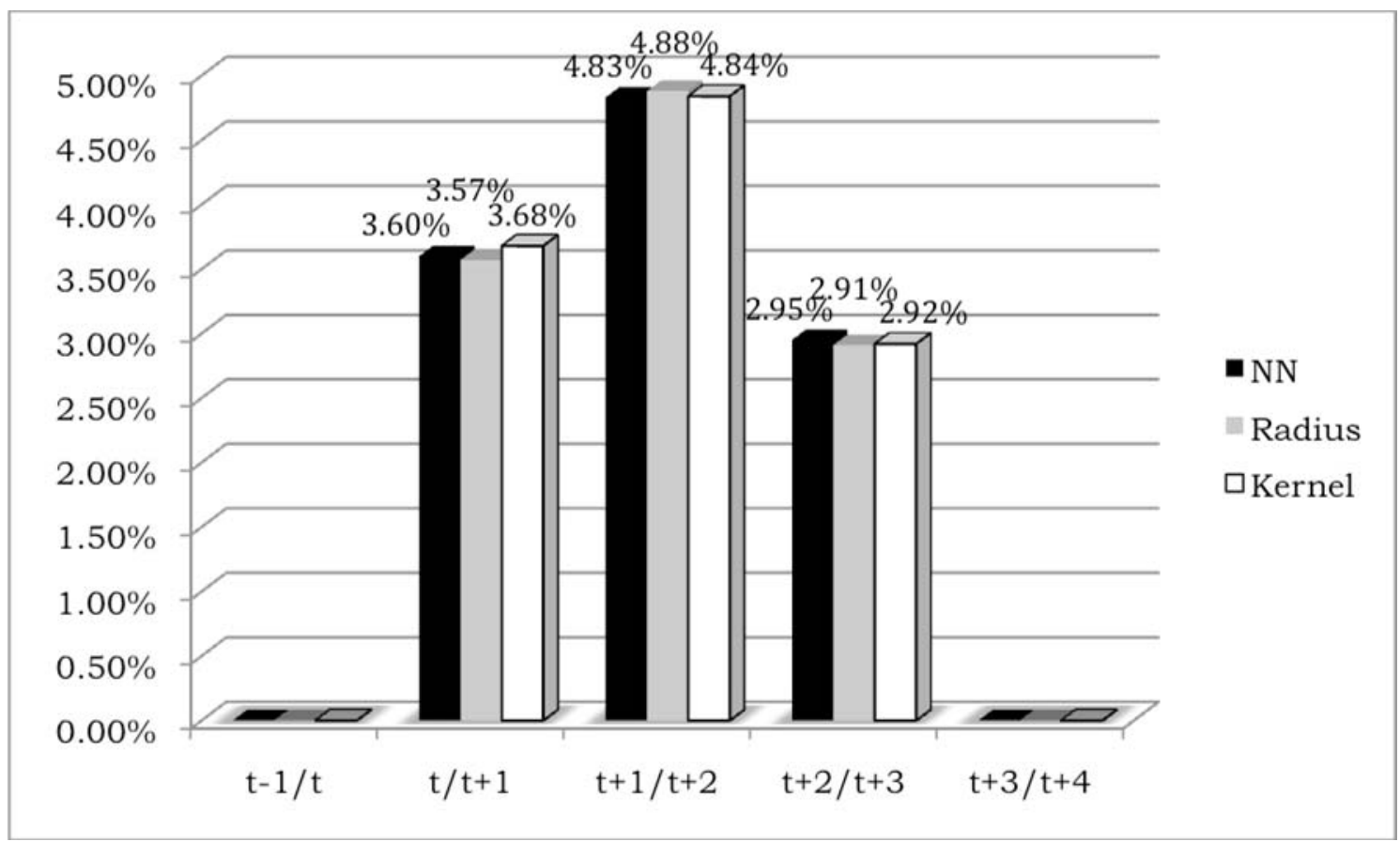

Note: NN stands for nearest-neighbours. 
Our findings are consistent with existing empirical literature reporting a positive impact of process innovations on productivity growth. Parisi et al. (2006), using a large sample of Italian firms, provide evidence on the positive impact of the introduction of process innovations on productivity growth, although they cannot fully address the selfselection problems due to data restrictions. Lee and Kang (2007) also provide evidence on a positive impact of process innovations on productivity growth using a sample of Korean manufacturing firms. Griffith et al. (2006) estimate the structural model of Crépon et al. (1998) using data from manufacturing firms in four countries. They find that in the case of France the introduction of process innovations is on average associated to a $6 \%$ increase in labour productivity (measured as sales per worker). However, for manufacturing firms in Germany, Spain and the UK they do not find this positive relationship between process innovations and productivity. Notwithstanding, Griffith et al. (2006) note two shortcomings in their study: on the one hand, they acknowledge that the lack of association between process innovations and productivity for Germany, Spain and the UK could be due to the fact that they are measuring revenue productivity deflated using industry deflators, instead of firm specific deflators; on the other hand, as they only have cross-sectional data, they are only able to recover correlations, and these are not necessarily casual relationships.

In the case of Spain, Huergo and Jaumandreu (2004) analyzed the productivity growth impact of process innovations introduced by firms taking into account their different ages, and using a sample of Spanish manufacturing firms. They found that a process innovation induces (a contemporaneous) 1.5\% extra productivity growth that tends to persist although attenuated, for 3 additional years. ${ }^{13}$ Rochina-Barrachina et al. (2008), using a sample of large and small Spanish manufacturing firms for the period 1991-1998, but without controlling for non-random selection into process innovation, provide evidence on a contemporaneous impact of process innovations on firm productivity growth, and found that this impact is larger and longer in the case of large firms. Thus, compared to the related literature analysing the impact of process innovations on productivity growth, when controlling for non-random selection into process innovation using matching techniques, ${ }^{14}$ we obtain a positive effect that it is not contemporaneous, but instead induces a one year delayed increase in productivity growth, which lasts three periods.

\footnotetext{
${ }^{13}$ Huergo and Jaumandreu (2004) use the same dataset than ours but for the period 1990-1998 and including large firms. They measure productivity growth by means of the Solow residual and estimate a semiparametric model, with special focus on firm's age.

${ }^{14}$ Parisi et al. (2006) found that the effect of the introduction of process innovations on productivity growth is positive over a period of three years. However, in their data, information on innovations is not available on a yearly basis but every three years. Thus, they cannot evaluate the time span of this effect. Gu and Tang (2003) provide empirical evidence, using a panel data sample of manufacturing industries, that (different measures of) innovations have a positive impact on productivity and that it takes from one to three years, depending on the industry, for innovations to raise productivity.
} 


\section{Concluding remarks}

In this paper we have provided panel data evidence on the causal links between the introduction of process innovations and productivity growth for a sample of Spanish manufacturing SMEs. First, using stochastic dominance techniques, we have found evidence on the existence of non-random selection into the introduction of process innovations. Therefore, in order to assess the impact of introducing process innovations on SMEs productivity growth, that is, to properly control for the direction of causality from implementing process innovations to productivity growth, we have used matching techniques, a methodology that explicitly takes into account this non-random selection process. We have found that the introduction of process innovations yields a delayed (not contemporaneous) extra productivity growth to a SME implementing a process innovation for the first time, as compared to a SME that does not introduce process innovations, and that the life span of this extra productivity growth has an inverted Ushaped form. Thus, our results suggest that process innovations may be considered as a strategic tool through which SMEs may enhance their competitive position in the market by boosting productivity growth. This is especially important as the competitive pressure intensifies as a result of increased globalization of markets. 


\section{Appendix}

Table A.1. The determinants of becoming a first-time process innovator

\begin{tabular}{|c|c|c|}
\hline & \multicolumn{2}{|c|}{$\begin{array}{l}\text { Probit regression of the probability of } \\
\text { becoming a first-time process innovator }\end{array}$} \\
\hline Export Intensity $_{\mathrm{t}-1}$ & 0.1669 & $(0.055)^{* * *}$ \\
\hline Significant market share ${ }_{t-1}$ & 0.0183 & $(0.022)$ \\
\hline $\log (\text { employment })_{\mathrm{t}-1}$ & 0.0384 & $(0.014)^{* * *}$ \\
\hline $\log (\mathrm{TFP})_{\mathrm{t}-1}$ & 0.1086 & $(0.042)^{* * *}$ \\
\hline Advertising intensityt-1 & 0.9934 & $(0.686)$ \\
\hline Foreign capital participation $\mathrm{t}_{\mathrm{t}-1}$ & -0.0022 & $(0.036)$ \\
\hline Legal form $\mathrm{t}_{\mathrm{t}-1}$ & 0.0578 & $(0.023)^{* * *}$ \\
\hline R\&D Intensity ${ }_{t-1}$ & 3.3588 & $(1.249)^{* * *}$ \\
\hline Complementary R\&D activitiest-1 & 0.0832 & $(0.024)^{* * *}$ \\
\hline Age & -0.0159 & $(0.001)^{* *}$ \\
\hline Number observations & \multicolumn{2}{|c|}{1663} \\
\hline
\end{tabular}

Notes:

(1) * significant at $10 \%$, ** significant at $5 \%$ and *** significant at $1 \%$.

(2) Robust standard errors in parentheses.

(3) The regression includes year dummies and 2-digit industry dummies. 


\section{REFERENCES}

Abadie, A., Drukker, D., Herr, J and G. W. Imbens, 2004, Implementing matching estimators for average treatment effects in Stata, The Stata Journal, 4(3), 290311

Abadie, A. and G.W. Imbens, 2006, On the Failure of the Bootstrap for Matching Estimators. NBER Technical Working Paper No. 325.

Acs, Z. J. and Audretsch, D. B., 1990, Innovation and Small Firms, Cambridge, Massachusetts: MIT Press.

Aghion, P. and Howitt, P.,1992, "A model of growth through creative destruction”, Econometrica, 60, 323-51.

Baldwin, J. R., 1997, “The importance of research and development for innovation in small and large Canadian manufacturing firms”, Research Paper 107, Analytical Studies Branch, Statistics Canada

Buckley, J.P. and Mirza, H., 1997, “Introduction”, in International Technology Transfer by Small and Medium Sized Enterprises, Buckley, J.P., Campos, J., Mirza, H., White, E. (eds.), Macmillan: Houndmills, UK, 1-5.

Caves, D.W., L.R. Christensen and E. Diewert, 1982, 'Multilateral comparisons of output, input and productivity using superlative index numbers', Economic Journal 92, 73-86.

Cohen, W. M. and Klepper, S. (1996). Firm size and the nature of innovation within industries: The case of process and product R\&D. Review of Economics and Statistics 78, 232-243

Crépon, B., Duguet, E. and Mairesse, J., 1998, "Research, Innovation and Productivity: An Econometric Analysis at the Firm Level”, Economics of Innovation and New Technology, 7, 115-158.

Davies, S., 1979, The Diffusion of Process Innovations, Cambridge University Press, Cambridge.

Delgado, M.J., J.C. Fariñas, and S. Ruano, 2002, "SMEs' productivity and the export markets,” Journal of International Economics, 57, 397-422. 
Ericson, R. and Pakes, A. (1992), “An alternative theory of firm and industry dynamics”, Cowles Foundation Discussion Papers 1041, Yale University.

Ericson, R. and Pakes, A. (1995), "Markov-perfect industry dynamics: a framework for empirical work”, Review of Economic Studies, 62, 53-82.

González, X. and Jaumandreu, J. (1998), “Threshold effects in product R\&D decisions: Theoretical framework and empirical analysis”, Studies on the Spanish Economy, FEDEA.

González, X., Jaumandreu, J. and Pazó, C., (1999), “Innovación, costes irrecuperables e incentivos a la I+D”, Papeles de Economía Española, 81, 155-166.

Good, D., Nadiri, I. M. \& Sickles, R. (1996). Index number and factor demand approaches to the estimation of productivity. NBER working paper 5790.

Griffith, R., Huergo, E., Mairesse, J. and Peters, B. (2006), 'Innovation and productivity across four European countries', Oxford Review of Economic Policy 22(4), pp. 483-498.

Griliches, Z. (1979), "Issues in assessing the contribution of R\&D to productivity growth”, Bell Journal of Economics, 10, 92-116.

Gu, W. and Tang, J. (2003). The link between innovation and productivity in Canadian manufacturing industries. Working Paper number 38, Industry Canada Research Publication Programme.

Hall, B. (1990). The impact of corporate restructuring on industrial R\&D. Brookings Papers on Economic Activity: Microeconomics, 85-124.

Handcock, M.S., and M. Morris, 1999, "Relative distribution methods in the social sciences”, New York: Springer-Verlag.

Heckman, J., H. Ichimura and P. Todd, 1997, "Matching as an econometric evaluation estimator”, Review of Economic Studies, 65, 261-294.

Huergo, E. and Jaumandreu, J. (2004), “Firm's age, process innovation and productivity growth”, International Journal of Industrial Organisation, 22, 541-559.

Klette, T. J. and Johansen, F. (1998). Accumulation of R\&D capital and dynamic firm performance: A not-so-fixed effect model. Annales d' Economie et de Statistique, 49/50, 389-419. 
Lee, K., and Kang, S.M., 2007, "Innovation types and productivity growth: evidence from Korean manufacturing SMEs”, Global Economic Review, 36, 343-359.

Leuven, E, and B. Sianesi, 2003. "PSMATCH2: Stata module to perform full Mahalanobis and propensity score matching, common support graphing, and covariate imbalance testing”, Statistical Software Components S432001, Boston College Department of Economics, revised 28 Dec 2006.

Máñez, J.A., Rincón, A., Rochina, M.E. and Sanchis, J.A., 2005, “Productividad e I+D: Un análisis no paramétrico”, Revista de Economía Aplicada, 39, 47-86.

Máñez, J. A., Rochina, M. E., Sanchis, A. and Sanchis, J. A., 2009, “The role of sunks costs in the decision to invest n R\&D”, Journal of Industrial Economics, forthcoming.

Pakes A. \& Ericson, R. (1998), "Empirical implications of alternative models of firm dynamics”, Journal of Economic Theory, 79, 1-45.

Parisi, M. L., Schiantarelli, F. and Sembenelli, A. (2006), "Productivity, innovation and R\&D: Micro evidence for Italy”, European Economic Review, 50, 20372061.

Pavitt, K., Robson, M., Townsend, J., 1987, “The size distribution of innovating firms in the UK: 145-983”, Journal of Industrial Economics, 35, 91-316.

Politis, D.N., Romano ,J.P., and Wolf, M., 1999, Subsampling, Springer-Verlag, New York.

Rochina-Barrachina, M.E., Máñez, J.A. and Sanchis-Llopis J.A., 2008, “Process innovations and firm productivity growth", Small Business Economics, DOI 10.1007/s11187-008-9110-5.

Romer, P., 1990, “Endogenous technological change”, Journal of Political Economy, 98-102.

Rosenbaum, P.R., and D. Rubin, 1983, “The central role of the propensity score in observational studies for causal effects”, Biometrika, 70, 41-55.

Rosenbaum, P.R., and Rubin, D.B., 1985, "Constructing a control group using multivariate matched sampling methods that incorporate the propensity score", The American Statistician, 39 (1), 33 - 38. 
Scherer, F.M., 1991, "Changing perspectives on the firm problem”, in Acs, Z. and Audretsch, D. (eds.), Innovation and Technological Change, Harvester Wheatsheaf, New York.

Schumpeter, J. A., 1934, The Theory of Economic Development, Harvard University Press, Cambridge, MA.

Schumpeter, J. A., 1942, Capitalism, Socialism and Democracy, New York: Harper and Row.

Smolny, W. (1998). Innovations, prices and employment: A theoretical model and an empirical application for West German manufacturing firms. The Journal of Industrial Economics, 3, 359-381.

Sutton, J. (1991). Sunk Costs and Market Structure. Massachussets: MIT Press.

Verspagen, B. (1999). European Regional Clubs: Do They Exist and Where Are They Heading? On the Economic and Technological Differences between European Regions. (In J. Adams and F. Pigliaru (Eds.), Economic Growth and Change: National and Regional Patterns of Convergence and Divergence. Cheltenham: Edward Elgar.) 


\section{PUBLISHED ISSUES ${ }^{*}$}

WP-EC 2008-01 “La orientación al mercado como determinante de la internacionalización de las nuevas empresas”

A. Blesa, M. Ripollés, D. Monferrer. March 2008.

WP-EC 2008-02 "El balance actuarial como indicador de la solvencia del sistema de reparto"

M.C. Boado-Peñas, C. Vidal. March 2008.

WP-EC 2008-03 “La influencia de la cultura sobre la búsqueda de información. El caso de la vivienda para 'turismo residencial' en la Costa Blanca”.

F.J. Sarabia, A. Kanther, J. F. Parra. April 2008.

WP-EC 2008-04 “Optimal CEO compensation and stock options”.

A. Jarque. April 2008.

WP-EC 2008-05 “Un análisis bayesiano de la variación temporal del escenario de compra de los hogares”.

C. Berné, P. Gargallo, N. Martínez, M. Salvador. May 2008.

WP-EC 2008-06 “Trade, tariffs and total factor productivity: the case of Spanish firms". M. Dovis, J. Milgram-Baleix. May 2008.

WP-EC 2008-07 “The negative effects of failed service recoveries”. A.Casado, J. Nicolau, F. Mas. May 2008.

WP-EC 2008-08 "Short-term electricity futures prices: evidence on the time-varying risk premium”.

J. Lucia, H. Torró. May 2008.

WP-EC 2008-09 "Wage, price and unemployment dynamics in the Spanish transition to EMU membership".

K. Juselius, J. Ordóñez. May 2008.

WP-EC 2008-10 “Determinantes de la divulgación de información previsional en España: un análisis de las empresas IBEX 35”.

M.C. Abad, F. Bravo, M. Trombetta. July 2008.

WP-EC 2008-11 “Testing capital-skill complementarity across sectors in a panel of Spanish regions”

F. Pérez-Sebastián. September 2008.

WP-EC 2008-12 "Edad y tamaño empresarial y ciclo de vida financiero" J. Sánchez-Vidal, J.F. Martín-Ugedo. September 2008.

WP-EC 2008-13 “The asymmetric effect of endowments on vertical intra-industrial trade”

J. Milgram, A.I. Moro. October 2008.

\footnotetext{
* Please contact Ivie's Publications Department to obtain a list of publications previous to 2008.
} 
WP-EC 2008-14 "Health shocks, household consumption, and child nutrition" A. Galiano, M. Vera-Hernández. December 2008.

WP-EC 2009-01 "The effects of immigration on the productive structure of Spanish regions"

J. Martín, G. Serrano, F. Requena. February 2009.

WP-EC 2009-02 “Corporate governance and impression management in annual press releases"

B. García, E. Guillamón-Saorín. March 2009.

WP-EC 2009-03 "Factores determinantes de la salida a Bolsa en España” J.E. Farinós, V. Sanchis. April 2009.

WP-EC 2009-04 "New challenges in competitiveness: knowledge development and coopetition"

C. Camisón-Zornoza, M. Boronat-Navarro, A. Villar-López. April 2009.

WP-EC 2009-05 "The determinants of net interest income in the Mexican banking system: an integrated model”

J. Maudos, L. Solís. April 2009.

WP-EC 2009-06 "Explaining protectionism support: the role of economic factors" N. Melgar, J. Milgram-Baleix, M. Rossi. April 2009.

WP-EC 2009-07 "Determinants of interest rate exposure of Spanish banking industry" L. Ballester, R. Ferrer, C. González, G.M. Soto. May 2009.

WP-EC 2009-08 "Entrepreneurial orientation, organizational learning capability and performance in the ceramic tiles industry"

J. Alegre, R. Chiva. June 2009.

WP-EC 2009-09 "El coste y el desequilibrio financiero-actuarial de los sistemas de reparto. El caso del sistema Español”

J.E. Devesa Carpio, M. Devesa Carpio. July 2009.

WP-EC 2009-10 “Imposición y protección social: efectos sobre el nivel de empleo en la OCDE”

J.R. García Martínez. July 2009.

WP-EC 2009-11 "The role of learning in innovation: in-house versus externally contracted R\&D experience"

P. Beneito, M.E. Rochina, A. Sanchis. October 2009.

WP-EC 2009-12 "Do process innovations boost SMEs productivity growth?

J.A. Máñez-Castillejo, M.E. Rochina-Barrachina, A. Sanchis-Llopis, J.A. Sanchis-Llopis. October 2009.

WP-EC 2009-13 “Esperanza de Vida Libres de Discapacidad por sexo y Comunidad Autónoma: 2004-2006”

F.J. Goerlich, R. Pinilla. October 2009. 


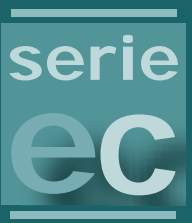

\section{I vie}

Guardia Civil, 22 - Esc. 2, 19

46020 Valencia - Spain

Phone: +34 963190050

Fax: +34 963190055

Website: http:/ / www.ivie.es

E-mail: publicaciones@ivie.es 